\title{
INVENTARISASI TUMBUHAN BAWAH BERKHASIAT OBAT DI TAMAN NASIONAL GUNUNG GEDE PANGRANGO PROVINSI JAWA BARAT BERBASISKAN ANALISIS SPASIAL
}

\author{
(Inventory Underground Plant as Source of Medicinal Plants from Gunung Gede Pangrango \\ National Park West Java Province with Spasial Anaysis Methods)
}

\author{
Yanieta Arbiastutie ${ }^{1,2 *}$, Djoko Marsono ${ }^{3}$, Wahyuningsih MSH $^{4}$, Rishadi Purwanto ${ }^{3}$ \\ ${ }^{1}$ Doctoral Program of Forestry Science, Faculty of Forestry, Universitas Gadjah Mada. Jl. Agro No. 1 Bulaksumur, Sleman 55281, \\ Yogyakarta,Indonesia. Tel./Fax.: +62-274-4550541, ’email: yannie_ta@yahoo.co.id \\ ${ }^{2}$ Faculty of Forestry, Universitas Tanjungpura. Jl. Daya Nasional Pontianak, West Kalimantan, Indonesia \\ ${ }^{3}$ Faculty of Forestry, Universitas Gadjah Mada. Jl. Agro No. 1, Bulaksumur, Sleman 55281, Yogyakarta, Indonesia \\ ${ }^{4}$ Faculty of Medicine, Universitas Gadjah Mada. Jl. Farmako, Sekip Utara, Sleman 55281, Yogyakarta, Indonesia
}

\begin{abstract}
Diversity of biological resources in primary forest is not only limited to the woody plant species, but also covered by underground plant which has diverse species high diversity. This underground plant as one part of the forest ecosystem is a plant that has potential as a medicine. The study aims to conduct an inventory of underground plant species in Gunung Gede Pangrango National Park West Java Province. The method for inventory used spasial analysis with land management unit and multi stage sampling. The spasial analysis used three categories, first the zonation map, second the soil characterization map and the third altitude map. The LMU consist of 6 areas with total plot number 60. The results showed there are 83 species underground plant consist of 45 family. The family consist of Acanthaceae, Annonaceae, Apiaceae, Apocynaceae, Araceae, Araliaceae, Aspleniaceae, Asteraceae, Balsaminaceae, Begoniaceae, Compositae, Convolvulaceae, Cucurbitaceae, Cyperaceae, Elaeagnaceae, Equisetaceae, Fabaceae, Gesneriaceae, Gramineae, Hypoxidaceae, Lamiaceae, Malvaceae, Marattiaceae, Melastomataceae, Menispermaceae, Moraceae, Musaceae, Myrsinaceae, Oxalidaceae, Passifloraceae, Piperaceae, Plantaginaceae, Polygalaceae, Primulaceae, Rosaceae, Rubiaceae, Sellagineaeeae, Smilaceae, Solanaceae, Symplocaceae, Urticaceae, Verbenaceae, Woodsiaceae, Zingiberaceae. The underground plant has a potential as medicinal plant.
\end{abstract}

Keywords: Gunung Gede Pangrango National Park, inventory, land management unit, medicinal plant, underground plant

\section{PENDAHULUAN}

Indonesia merupakan salah satu negara yang memiliki hutan hujan tropis yang sangat luas. Smith (1990) menyatakan ekosistem hutan hujan tropis memiliki tingkat keanekaragaman hayati yang tinggi karena adanya kondisi habitat yang heterogen, baik secara vertikal maupun horisontal. Kondisi habitat yang bervariasi memberikan peluang berbagai spesies tumbuhan untuk hidup bersama dalam ekosistem, salah satu diantaranya adalah spesies tumbuhan bawah.

Tumbuhan bawah merupakan komponen vegetasi dasar di bawah tegakan hutan selain permudaan pohon, yang terdiri atas rerumputan, herba dan semak belukar. Kelompok vegetasi ini memiliki peranan penting dalam menjaga stabilitas ekosistem hutan (Soerianegara dan Indrawan, 2008), selain itu Hardjosumarno (1998) menjelaskan komposisi dan keanekara 
gaman jenis tumbuhan bawah berfungsi untuk mempertahankan siklus hidrologi, penyedia bahan organik, dan menjaga kelembaban tanah. Hilwan et al. (2013) menyatakan tumbuhan bawah selain memiliki fungsi ekologi juga memiliki manfaat ekonomi yang dapat dikem bangkan, salah satunya sebagai sumber bahan obat. Pemanfaatan tumbuhan bawah sebagai sumber bahan obat merupakan alternatif yang dapat diusaha kan untuk mendorong pengembangan hasil hutan bukan kayu dari kawasan hutan hutan hujan tropis.

Tumbuhan bawah yang terdapat di dalam kawasan Taman Nasional Gunung Gede Pangrango memiliki potensi sebagai bahan obat-obatan. Zainuddin (2008) dan Whitmore (1984) menyatakan setiap tipe ekosistem hutan tropika di Indonesia merupakan pabrik keaneka ragaman hayati tumbuhan obat, terbentuk secara evolusi dengan waktu yang sangat panjang, telah dimanfaat kan masyarakat lokal berdasarkan pengalaman secara turun temurun. Cutler (2000) menyatakan keanekaraga man jenis tumbuhan hutan hujan tropis sangat tinggi karena terdapat perbedaanperbedaan iklim yang nyata terutama perbedaan yang berhubungan dengan ketinggian di atas permukaan air laut. Menurut Marsono (2004) sumber daya alam hayati yang dimanfaatkan manusia dalam bentuk jenis, gen dan ekosistemnya, selain itu nilai subtansial konservasi sumber daya alam hayati adalah terhadap nilai ekonomis dan komponen bioaktif serta sumber plasma nutfahnya. Zuhud (2008) telah melakukan inventarisasi jenis tumbuhan di beberapa taman nasional dan hasil penelitian menunjukkan setiap unit kawasan taman nasional ditemukan berbagai spesies tumbuhan obat yang dapat mengobati 25 kelompok penyakit yang diderita masyarakat, sehingga dapat disimpulkan bahwa setiap kawasan hutan alam tropika pada setiap tempat menyediakan bahan baku obat untuk berbagai kelompok masyarakat.

Penelitian bertujuan untuk melaku kan inventarisasi komunitas tumbuhan bawah berkhasiat obat yang terdapat di Taman Nasional Gunung Gede Pangrango dengan menggunakan analisis spasial. Analisis spasial dilakukan untuk mengkaji faktor dari zonasi, jenis tanah dan ketinggian tempat terhadap keanekaragaman tumbuhan bawah.

\section{METODE PENELITIAN}

\section{A. Tempat dan Waktu Penelitian}

Lokasi penelitian di kawasan Resort Cibodas, Taman Nasional Gunung Gede Pangrango (TNGGP). Resort Cibodas secara administratif terletak di Desa Cimacan, Kecamatan Pacet, Kabupaten Cianjur. Luas Resort Cibodas 1.750,81 ha dengan luas keseluruhan TNGGP 21.975 ha menurut SK Penetapan Kawasan TNGGP No. 3683/Menhut-VII/KUH/2014 seperti terlihat pada Gambar 1. Penelitian dilaksanakan pada bulan November 2014 sampai Desember 2015. 


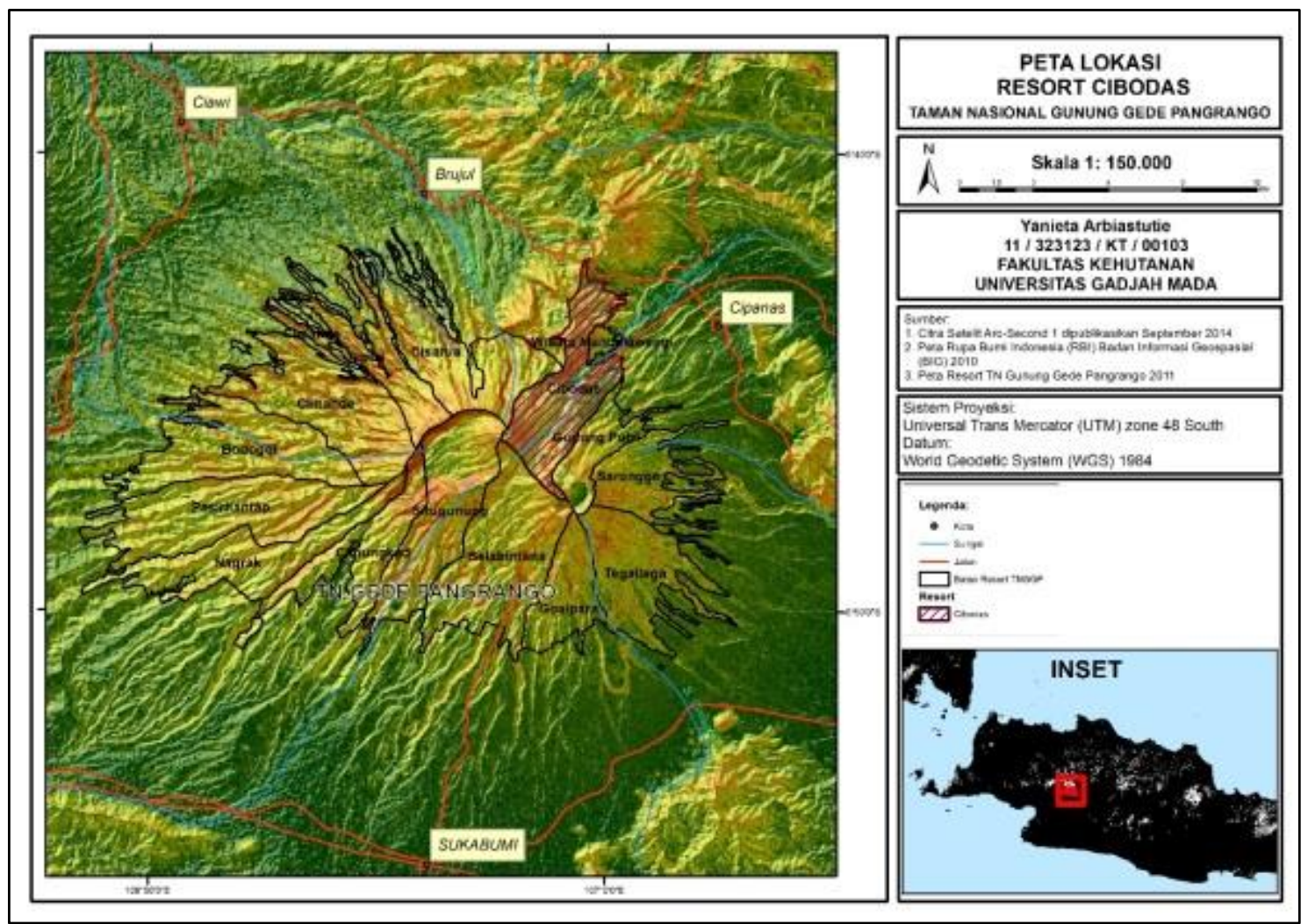

Gambar 1. Peta Lokasi Resort Cibodas TNGGP

\section{B. Prosedur Penelitian}

\section{Penyusunan LMU dan Petak Ukur (Multi-Stage Sampling)}

Penyusunan peta unit lahan diperoleh menggunakan analisis spasial yang merupakan teknik atau proses yang melibatkan sejumlah hitungan dan evaluasi logika (matematis) yang dilakukan dalam rangka mencari atau menemukan potensi hubungan atau pola-pola yang terdapat diantara unsurunsur keruangan. Penyusunan dilakukan dengan operasi timpang tindih meng gunakan perangkat lunak ArcGIS 10.1. Peta yang dihasilkan berisi informasi yang detail dari semua peta dasar yang digabungkan. Output dari hasil overlay berupa Land Mapping Unit (LMU), jadi dapat dikatakan LMU adalah unit kawasan yang seragam menurut kriteria tertentu (Soeprijadi et al, 2012), kemudian dilakukan penentuan lokasi untuk pembuatan petak ukur berupa nested sampling untuk pengambilan sampel tumbuhan bawah dan tingkat pertumbuh an vegetasi.

Multi-stage sampling merupakan sampling bertahap, tahap pertama dilakukan sampling dengan membagi kawasan menjadi kelas-kelas unit lahan dengan karakteristik yang seragam berupa peta unit lahan, lalu dilakukan pencuplikan tahap kedua untuk setiap kelas unit lahan dengan pembuatan petak ukur. Proses tersebut lebih jelasnya dapat dilihat dalam bagan seperti dalam Gambar 2. Land Mapping Unit (LMU) yang terbentuk dan 
JURNAL TENGKAWANG (2017)

Vol. 7 (1) : 28 - 45

informasi awal tentang jenis tumbuhan

digunakan sebagai dasar peletakan bawah berpotensi obat selanjutnya posisi dan pembuatan petak ukur.
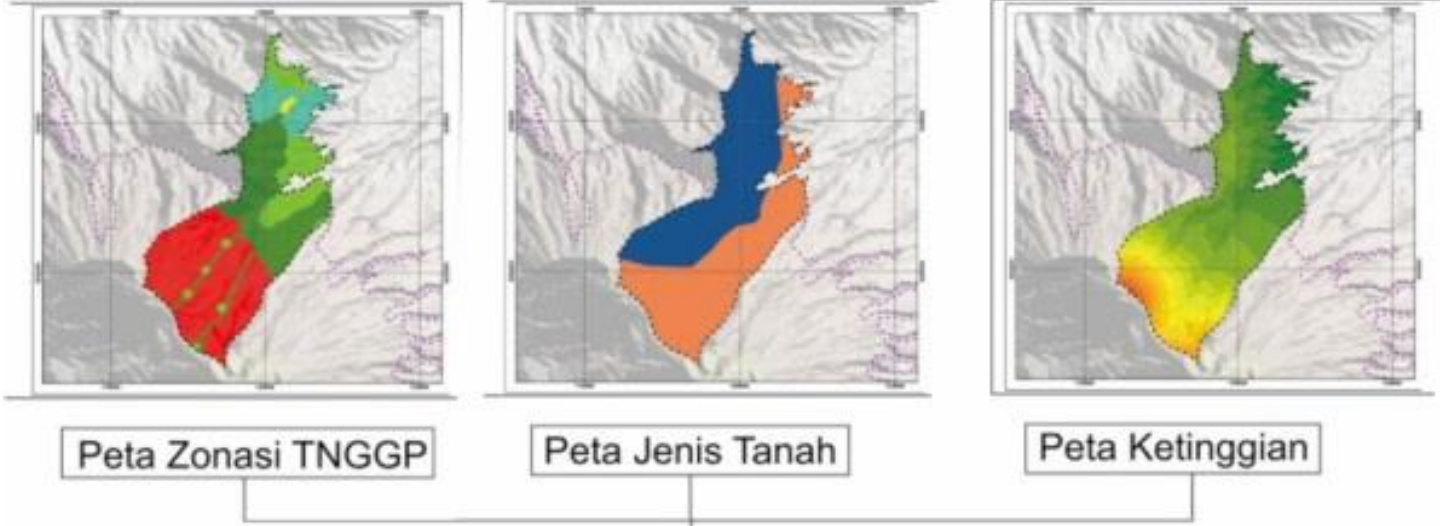

Peta Ketinggian



Gambar 2. Bagan Overlay untuk pembuatan LMU dan Lokasi Petak Ukur 
Pembuatan Petak Ukur Tumbuhan Bawah dan Tingkat Pertumbuhan Vegetasi

Pembuatan dan penempatan petak ukur berada pada tiap LMU dilakukan dengan mempertimbangkan kondisi topografi dan komposisi tumbuhan bawah. Berdasarkan pendekatan ini kemudian petak ukur ditempatkan searah garis kontur yang berada di kanan dan kiri jalur pendakian.

Teknik sampling yang digunakan untuk pengumpulan data adalah multistage sampling. Stage pertama menge lompokkan satuan unit lahan berdasar kan karakteristik fisik kawasan yang seragam, sedangkan stage kedua adalah petak ukur di dalam stage pertama. Petak ukur untuk pengambilan sampel berupa nested sampling. Rancangan petak ukur nested sampling berupa petak ukur bertingkat, dimana setiap sub-petak ukurnya berbentuk 4 (empat) persegi berurutan sebanyak 5 (lima) petak ukur dalam satu jalur, kemudian dilakukan pembuatan lima petak ukur selanjutnya pada jalur kedua dengan jarak antar jalur adalah 50 meter. Hal tersebut dilakukan seterusnnya hingga dirasa jumlah petak ukur telah memenuhi kebutuhan penelitian. Bentuk, ukuran dan sebaran sub-plot dalam petak ukur ditunjukkan pada Gambar 3.



Gambar 3. Rancangan petak ukur nested sampling

Satu plot terdiri atas beberapa sub plot. Sub-plot berukuran $2 \mathrm{~m}$ x $2 \mathrm{~m}$ untuk pengukuran semai (seedling) dan tumbuhan bawah, sub-plot berukuran 5 $\mathrm{m} \times 5 \mathrm{~m}$ untuk tingkat pancang atau sapihan (sapling), sub-plot berukuran
$10 \mathrm{~m} \times 10 \mathrm{~m}$ untuk tingkat tiang (poles), dan sub-plot berukuran $20 \mathrm{~m}$ x $20 \mathrm{~m}$ untuk tingkat pohon (tree). Parameter vegetasi yang diukur disajikan pada Tabel 1. 
Tabel 1. Parameter pengukuran kondisi vegetasi

\begin{tabular}{lll}
\hline No. & Tingkatan Vegetasi & Paremeter Pengukuran \\
\hline 1 & Tumbuhan bawah & jenis, berat kering \\
2 & Semai & jenis, jumlah individu \\
3 & Sapihan & jenis, jumlah individu \\
4 & Tiang & jenis, diameter, jumlah individu \\
5 & Pohon & jenis, diameter, jumlah individu \\
\hline
\end{tabular}

Sumber: Odum, 1993

Pengumpulan data kondisi biofisik dilakukan pada setiap petak ukur. Parameter biofisik yang diamati meli puti ketinggian tempat, intensitas caha ya, suhu lingkungan, kelembaban ling kungan, ketebalan seresah, jenis tanah, suhu tanah, kelembaban tanah, kan dungan bahan organik, kandungan nitro gen, dan kapasitas tukar kation. Pengukuran intensitas cahaya, suhu lingkungan, dan kelembaban lingkung an dilakukan secara serentak pada setiap petak ukur dengan tiga replikasi waktu pengamatan yaitu pukul $08.00-09.00$ WIB, pukul 12.00 - $13.00 \mathrm{WIB}$, dan pukul 15.00 - 16.00 WIB.

\section{Identifikasi Jenis Tumbuhan Bawah Berpotensi Obat}

Identifikasi jenis dilakukan di lokasi petak ukur, apabila tidak dapat dilaku kan identifikasi di lokasi, maka akan diambil sampel guna dilakukan identifi kasi lebih lanjut dengan metode herbarium. Identifikasi sampel tumbuh an bawah dilakukan dengan kemampu an pengamat berbekal ilmu dendrologi dan pengenalan jenis tumbuhan bawah.

Herbarium dibuat dari spesimen yang telah dewasa, tidak terserang hama, penyakit atau kerusakan fisik lain. Tumbuhan berbentuk herba disertakan seluruh habitus. Herbarium kering digunakan untuk spesimen yang mudah dikeringkan, misalnya daun, batang, bunga dan akar (Setyawan dkk, 2005).

Metode ini dilakukan dengan melaku kan pengambilan sampel herbarium yang harus memenuhi tujuan pembuatan herbarium, yakni untuk identifikasi dan dokumentasi. Herbarium yang telah diawetkan dikirim ke Laboratorium Botani LIPI, Bogor untuk diidentifikasi jenisnya lebih lanjut. Pengambilan data identifikasi jenis tumbuhan bawah menggunakan tally sheet (Tabel 2)

Tabel 2. Tally Sheet Jenis Tumbuhan Bawah

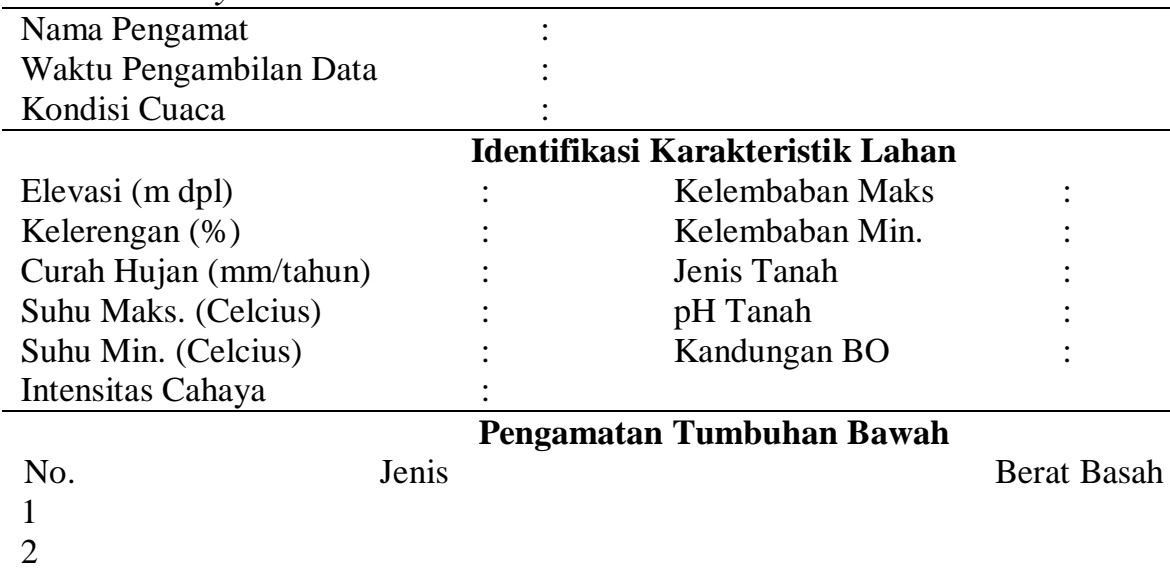




\section{HASIL DAN PEMBAHASAN} Multi-stage Sampling (Land Mapping Unit dan Petak Ukur)

Penelitian ini menggunakan multistage sampling sebagai metode dalam proses pengambilan data sampel jenis tumbuhan bawah, dikarenakan luasan Resort Cibodas yang cukup luas, yaitu sebesar 1,750.81 Ha. Multi-stage sampling dipilih karena metode tersebut dapat diterapkan pada penelitian yang kompleks dalam luasan wilayah penelitian dan parameter-parameter untuk pengukuran populasi/komunitas. Populasi/komunitas yang akan disampling dipilah berdasarkan unit sampling. Unit sampling dalam multistage sampling dipilih dalam urutan hierarki.Multi-stage sampling penelitian ini merupakan multi-stage sampling dua tahap/two-step sampling. Tahap pertama dalam pembagian kawasan menjadi unit-unit lahan dengan dasar karakteristik fisik yang seragam di kawasan TNGGP. Tahap kedua adalah keterwakilan unit lahan dengan pembuatan petak ukur sebagai unit sampling.

Pengelolaan taman nasional didasarkan pada pembagian zonasi pengelolaan, hal ini digunakan sebagai dasar dalam penentuan peta unit lahan dalam penelitian ini. Penentuan unit lahan dalam penelitian ini menggunakan peta ketinggian, peta jenis tanah dan peta zonasi Resort Cibodas TNGGP. Peta dasar yang digunakan sebagai bahan untuk pembuatan unit lahan dapat dilihat pada Gambar 4.

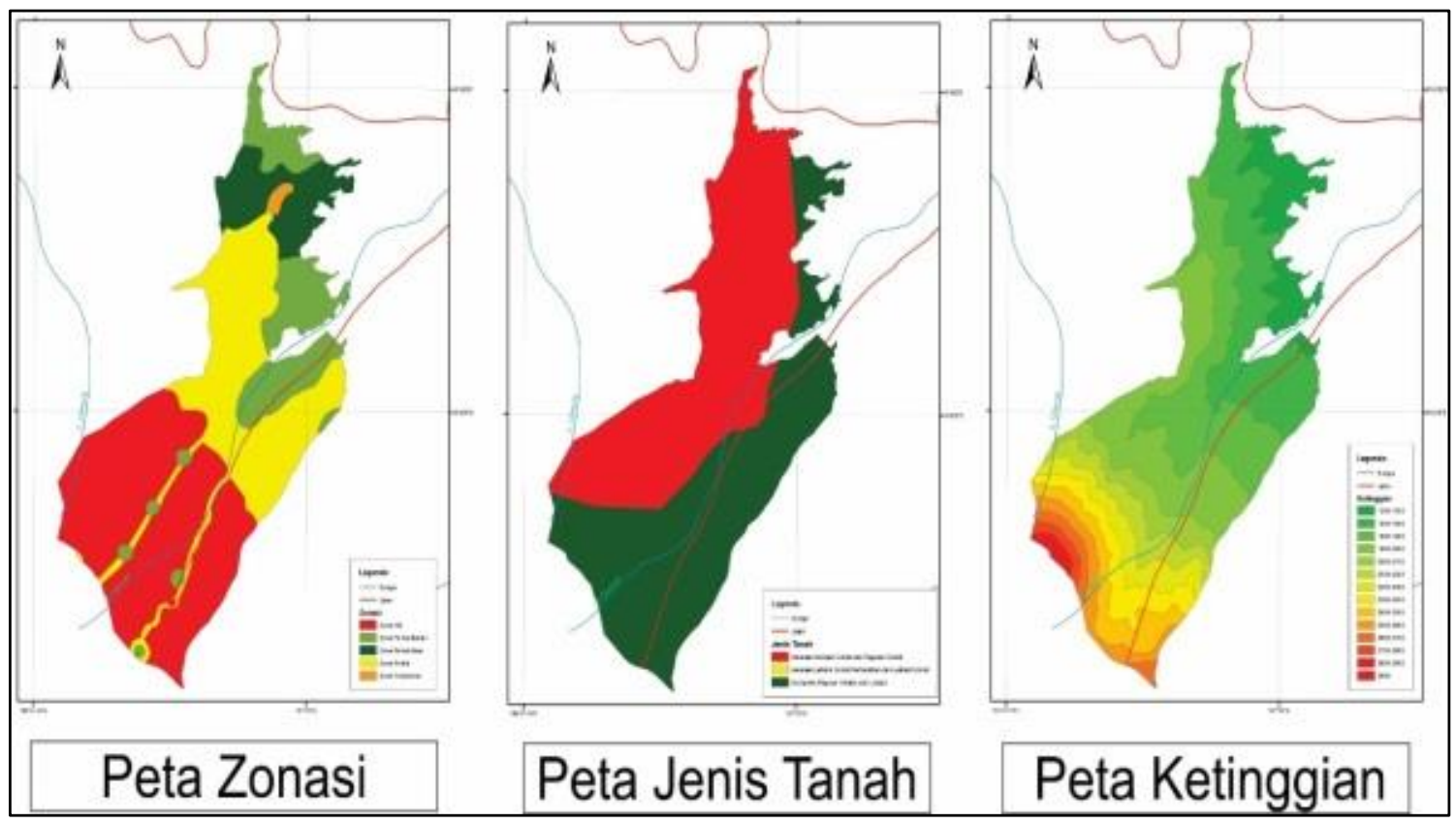

Gambar 4. Peta Dasar untuk Penyusunan LMU 
Tiga peta dasar yang digunakan dengan pertimbangan-pertimbangan yang sejalan dengan penelitian ini. Peta jenis tanah digunakan disebabkan faktor pertumbuhan tanaman dipengaruhi oleh keberadaan jenis tanah sebagai penyedia unsur hara dan tempat tumbuh dari komunitas tumbuhan bawah. Supriyono (2009) dan Hardjowigeno (2003) menyatakan bahwa perbedaan jenis tanah akan menyebabkan perbedaan komunitas tumbuhan bawah yang tumbuh. Peta ketinggian digunakan sebagai dasar pembuatan LMU karena pertumbuhan komunitas tumbuhan sangat dipengaruhi oleh faktor ketinggian (Searles et al., 2001; Zidorn, 2009). Faktor ketinggian akan menyebabkan perbedaan faktor-faktor pertumbuhan yang lain, terutama yang berkaitan dengan klimatologi dan hidrologi. Zonasi kawasan taman nasional merupakan dasar pembagian kawasan untuk pengelolaan taman nasional. Mengacu pada Undangundang No 5 Tahun 1990 tentang keanekaragaman hayati dan ekosistemnya, zona pemanfaatan adalah bagian taman nasional yang letak, kondisi dan potensi alamnya yang terutama dimanfaatkan untuk kepentingan pariwisata alam dan kondisi/jasa lingkungan lainnya. Peruntukan zona pemanfaatan untuk pengembangan pariwisata alam dan rekreasi, jasa lingkungan, pendidikan, penelitian dan pengembangan yang menunjang pemanfaatan, kegiatan penunjang budidaya. Pembuatan LMU menggunakan peta zonasi TNGGP agar diperoleh lokasi yang sesuai dengan tujuan untuk pengelolaan jenis tumbuhan bawah berpotensi sitotoksik teraktif kedepan.Proses overlay peta tersebut dilakukan denngan perangkat lunak ArcGIS 10.1, proses overlay dapat dilihat dalam Gambar 5.

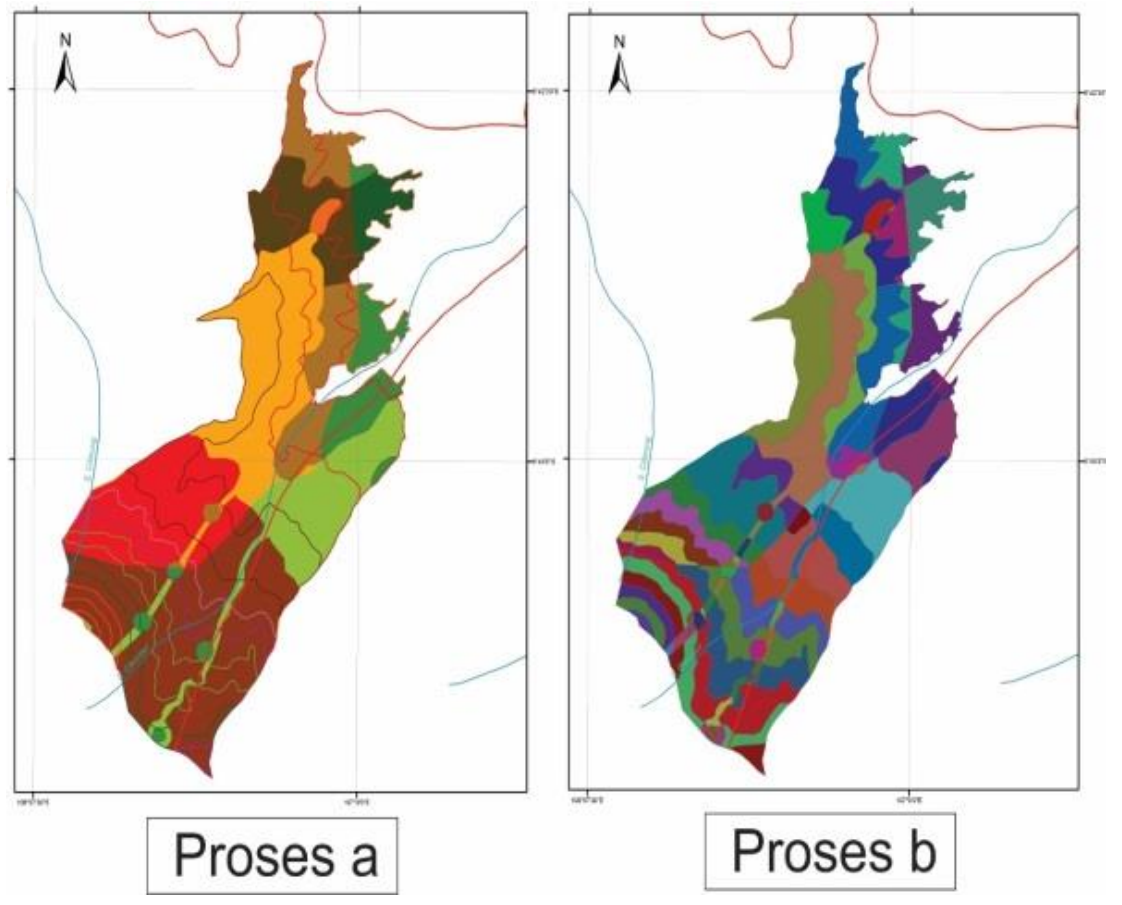


Gambar 5. Peta dalam proses overlay peta dasar; (proses a) adalah tampilan saat peta ditumpangtindihkan; (proses b) adalah hasil setelah dilakukan operasi overlay

Pada peta proses b pada Gambar 5 dapat dilihat satuan unit lahan dengan karakteristik-karakteristik tertentu.
Karakater unit lahan pada peta proses $b$ Gambar 5 dijelaskan dalam legenda seperti Gambar 6.

\begin{tabular}{|c|c|}
\hline \multicolumn{2}{|l|}{ Jenis tanah, Elevation, Zonasi } \\
\hline Ascsiasi Andosol Coklat dan Regosol Coklat, 1200-1400, Zona Pemanfaatan & Kompleks Regosol Kelabu dan Litosol, 1600-1800, Zona Pemanfaatan \\
\hline Ascsiasi Andosol Coklat dan Regosoi Coklat, 1200-1400, Zona Rehabītasi & Kompleks Regosol Kelabu dan Litosol, 1600-1800, Zona Römba \\
\hline Asosiasi Andosol Coklat dan Regosol Coklat, 1200-1400, Zona Tradisional & Komplekes Regosol Kelabu dan Litosol, 1800-2000, Zona int \\
\hline Asosiasi Andosol Coklat dan Regosol Coklat, 1400-1600, Zona Pemantatan & | Kompleks Regosol Kelabu dan Litbsol, 1800-2000, Zona Fúmba \\
\hline | Asosias Andosol Cokbat dan Ragososo Coklat, 1400-1600, Zona Rehabiltasi & Kompleks Regosol Kelabu dan Litosol, 2000-2100, Zona in6 \\
\hline Asosiasi Andosol Coklat dan Regosol Coklat, 1400-1600, Zona Rimba & Kompleks Regosol Kelabu dan Littssol, 2000-2100, Zona Rumba \\
\hline | Asosiasi Andosol Coklat dan Regosol Cokitat, 1400-1600, Zona Tradisional & Kompleks Regosol Kelabu dan Litosol, 2100-2200, Zona int \\
\hline Asosias Andosol Cokbat dan Regosol Coklat, 1600-1800, Zona Inf & Kompleks Regosol Kelabu dan Litosol, 2100-2200, Zona Pemantaatan \\
\hline Asosiasi Andosol Coklat dan Regosol Cokitat, 1600-1800, Zona Pentantatan & Kompleks Regosol Kelabu dan Litosol, 2100-2200, Zona Fimba \\
\hline Asosiasi Andosol Coklat dan Regosol Cokkat, 1600-1800, Zona Rehabïtasi & Kompleks Regosol Kelabu dan Litosol, 2200-2300, Zona int \\
\hline Asosiasi Andosol Coklat dan Regosol Coklat, 1600-1800, Zona Rimba & Kompleks Regosol Kelabu dan Litosol, 2200-2300, Zona Pemantaatan \\
\hline Asosiasi Andosol Coklat dan Regosol Cokkat, 1800-2000, Zona ins & Kompleks Regosol Kelabu dan Lilosol. 2200-2300, Zona Fümba \\
\hline Ascsiasi Andosol Coklat dan Regosol Cokiat, 1800-2000, Zona Pemanfastan & Kompleks Regosol Keiatu dan Littosol, 2300-2400, Zona inf \\
\hline Asosiasi Andosol Coklat dan Regosol Cokiat, 1800-2000, Zona Rimba & Kompleks Regosol Kelabu dan Litosol, 2300-2400, Zona Pemanfatan \\
\hline Ascsiass Andosol Coklat dan Regosol Coklat, 2000-2100, Zona int & Kompleks Regegosol Kelabu dan Litosol, 2300-2400, Zona Rímba \\
\hline Asosiass Andosol Coklat dan Regosol Cokkat, 2000-2100, Zona Rimba & | Kompleks Regosol Kelabu dan Litosol, 2400-2500, Zona int \\
\hline Asosiasi Andosol Coklat dan Regosol Coktak, 2100-2200, Zona Int & Kompleks Regosol Kelatu dan Litosol, 2400-2500, Zona Pemanfaatan \\
\hline Asosiasi Andosol Coklat dan Regosol Cokkat, 2100-2200, Zona Pemanfaatan & Kompleks Regosol Kelabu dan Litosol, 2400-2500, Zona Rümba \\
\hline Asosias Andosol Coklat dan Regosol Cokkat, 2100-2200, Zona Rimba & Kompleiks Regosol Kelatu dan Litosol, 2500-2600, Zona int \\
\hline Ascsiasi Andosol Cokkat dan Regosol Coklat, 2200-2300, Zona Ins & Kompleks Regosol Kelabu dan Litosol, 2500-2600, Zona Pemantaatan \\
\hline Asosiasi Andosol Coklat dan Regosol Coklat, 2300-2400, Zona Inf & Kompleks Regosol Kelabu dan Litosol, 2500-2600, Zona Rümba \\
\hline Asosiasi Andosol Coklat dan Regosol Coklat, 2400-2500, Zona int & Kompleks Regosol Kelabu dan Litosol, 2600-2700, Zona Int \\
\hline Asosiass Latosol Cokjat Kemerahan dan Latosol Coijat, 1400-1000, Zona Pemantaatan & Kompleks Regosol Kelabu dan Litosol, 2600-2700, Zona Fimba \\
\hline Kompleks Regosol Kelabu dan Littosol, 1200-1400, Zona Pemantaatan & Kompleks Regosol Kelatu dan Littosol, 2700-2800, Zona int \\
\hline Kompleks Regossi Kelabu dan Litosol, 1200-1400, Zona Rehabïtasi & Kompleks Regosol Kelabu dan Litosol, 2700-2800, Zona Fümba \\
\hline Kompleks Regosol Kelabu dan Litosol, 1400-1600, Zona Pemantaatan & Kompleiks Regosol Kelabu dan Litosol, 2800-2900, Zona int \\
\hline Kompleks Regosol Kelabu dan Litosol, 1400-1600, Zona Rehabiïtasi & Kompleks Regosoi Kelabu dan Litosol 2900, Zona int \\
\hline Kompleks Regosol Kelabu dan Litosol, 1400-1600, Zona Rimba & Komplekes Regosol Kelabu dan Liftosol, 2900, Zona Rümba \\
\hline Kompleks Regosol Kelabu dan Litosol, 1600-1800, Zona Int & \\
\hline
\end{tabular}

Gambar 6. Unit Lahan Hasil Proses Overlay Peta Dasar LMU

Pembuatan LMU merupakan tahapan pertama dalam multi-stage sampling. Dari hasil proses tersebut akan digunakan sebagai dasar proses tahap dua, yaitu pembuatan petak ukur untuk sampling jenis dan pengambilan data parameter lingkungan abiotik dan biotik. Proses pembuatan peta unit lahan secara utuh disajikan dalam Gambar 7. 
JURNAL TENGKAWANG (2017)

Vol. 7 (1) : 28 - 45
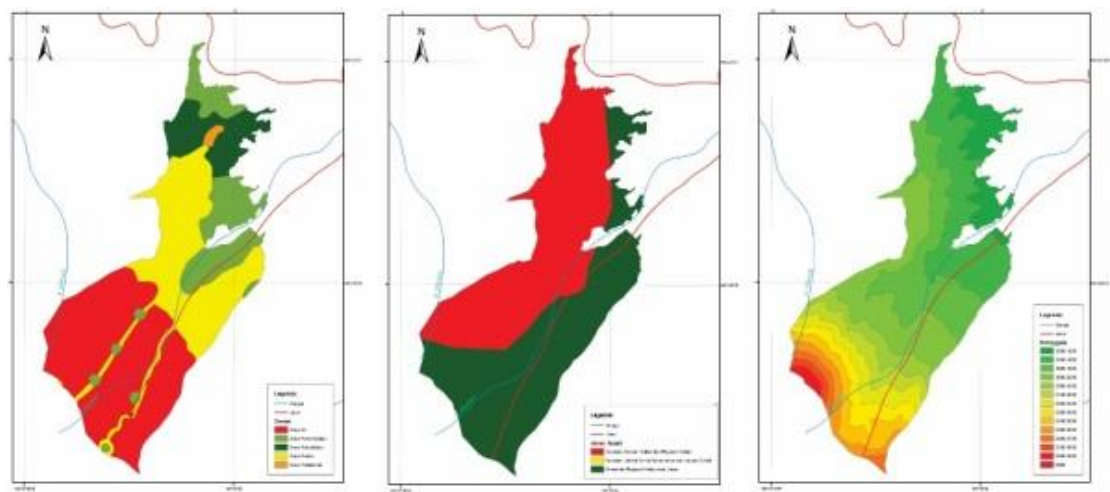

\section{Peta Zonasi \\ Peta Jenis Tanah \\ Peta Ketinggian}
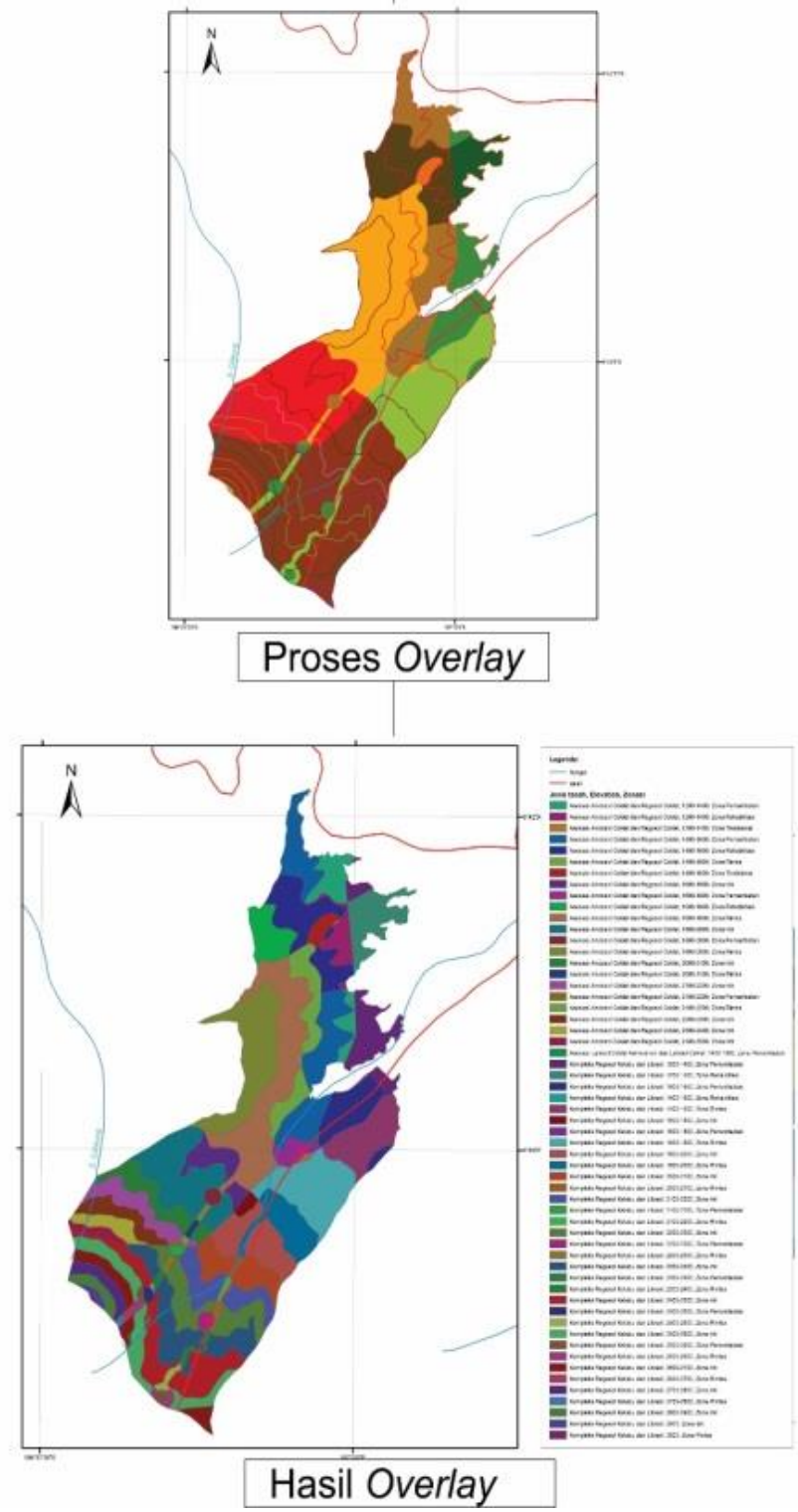

Gambar 7. Proses utuh Pembuatan Peta Unit Lahan 
JURNAL TENGKAWANG (2017)

Vol. 7 (1) : 28 - 45

Berdasarkan karakteristik lahan dalam tahap pertama dalam multi-stage sampling, diperoleh satuan unit-unit lahan dengan karakteristik yang seragam. Berdasarkan unit-unit lahan tersebut kemudian diklasifikasikan berdasarkan kriteria yang sesuai berdasarkan ketinggian, jenis tanah dan zona pemanfaatan yang sesuai dengan tujuan penelitian ini. Peta LMU setelah diklasifikasikan dapat dilihat pada Gambar 8.

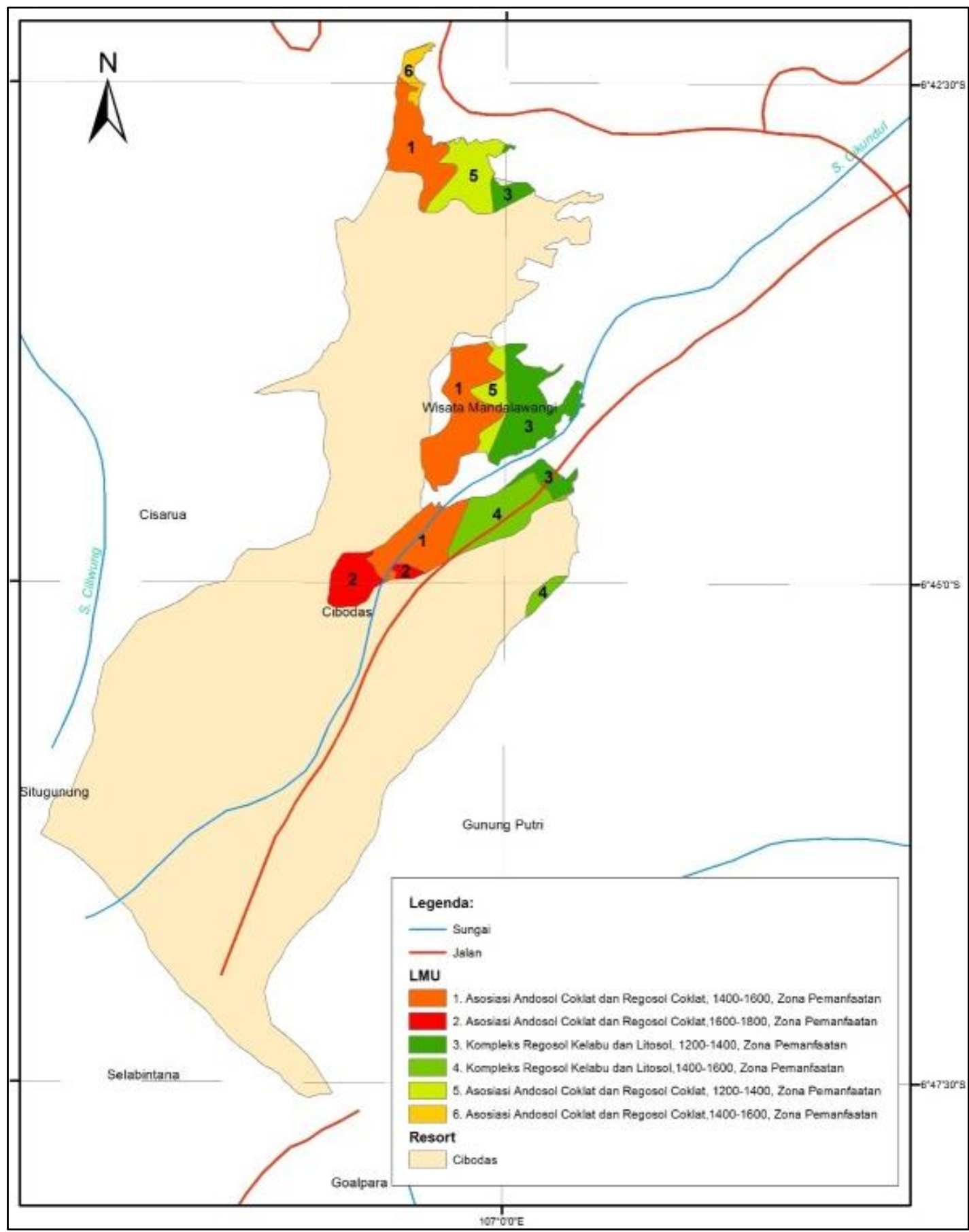

Gambar 8. Peta LMU setelah diklasifikasikan karakteristik dasarnya 
Karakter setiap unit-unit lahan yang dipilih yang sesuai dengan ruang lingkup penelitian merupakan unit-unit lahan yang selanjutnya akan digunakan Tabel 3. Karakter Unit Lahan dalam LMU dan Luasannya

\begin{tabular}{clr}
\hline LMU & Karakter Unit Lahan (Jenis Tanah, Ketinggian/mdpl, Zona) & Luas (Ha) \\
\hline 1 & Asosiasi Andosol Coklat dan Regosol Coklat, 1400-1600, Zona Pemanfaatan & 117.99 \\
2 & Asosiasi Andosol Coklat dan Regosol Coklat, 1600-1800, Zona Pemanfaatan & 21.76 \\
3 & Kompleks Regosol Kelabu dan Litosol, 1200-1400, Zona Pemanfaatan & 58.22 \\
4 & Kompleks Regosol Kelabu dan Litosol, 1400-1600, Zona Pemanfaatan & 40.90 \\
5 & Asosiasi Andosol Coklat dan Regosol Coklat, 1200-1400, Zona Pemanfaatan & 42.78 \\
6 & Asosiasi Andosol Coklat dan Regosol Coklat, 1400-1600, Zona Pemanfaatan & 7.07 \\
\hline
\end{tabular}

Tahap kedua adalah penentuan lokasi petak ukur yang didasarkan beberapa pertimbangan. Pertimbanganpertimbangan yang digunakan yaitu luasan unit lahan yang diperoleh pada tahap pertama, aksesibilitas lokasi dan informasi sekunder tentang keberadaan komunitas tumbuhan bawah. Pembuatan petak ukur dilakukan dengan nested sebagai dasar dalam pembuatan petak ukur. Karakter unit lahan dan luasannya dapat dilihat dalam Tabel 3. 
Vol. 7 (1) : 28 - 45

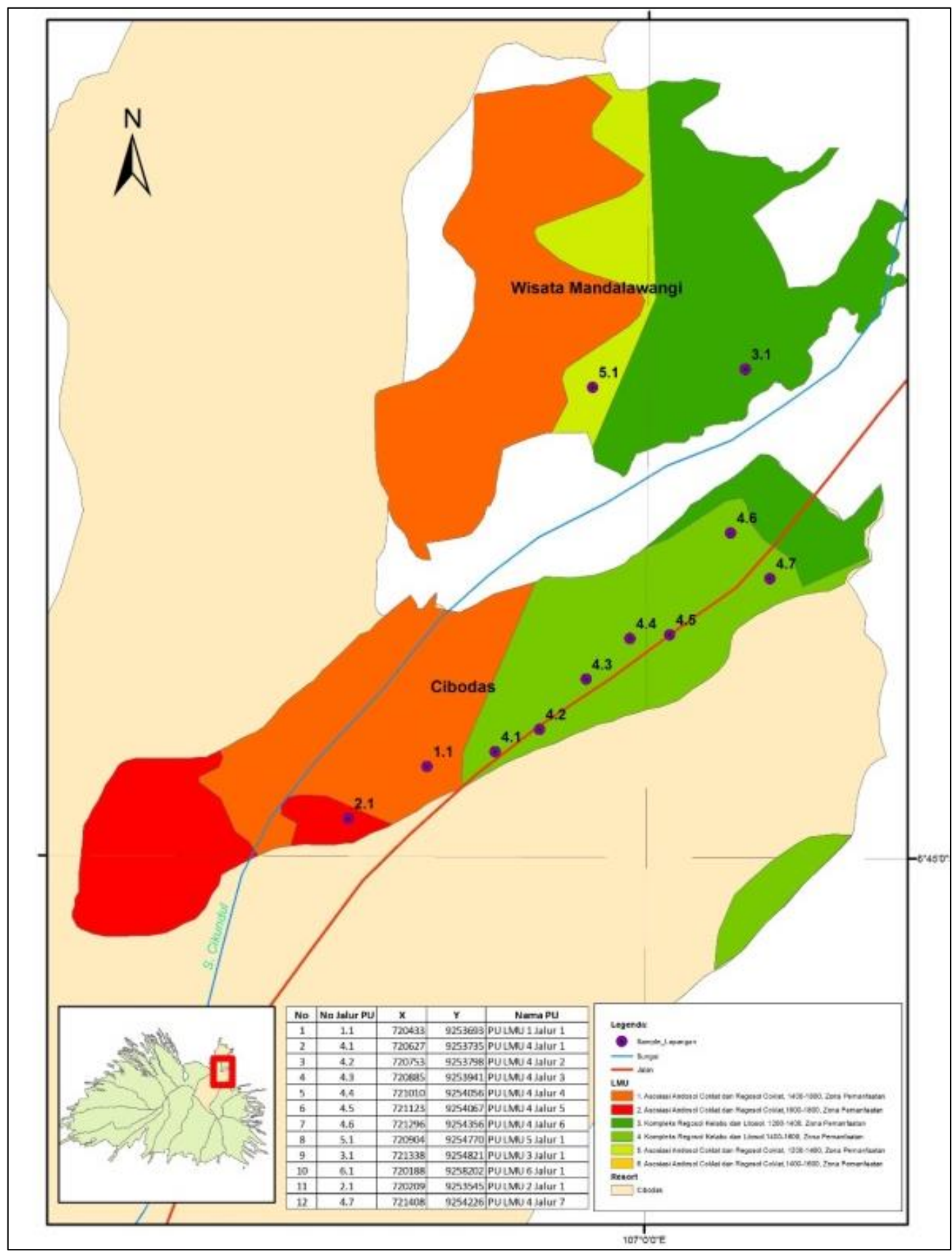

Gambar 9. Lokasi Pembuatan Petak Ukur

Pengambilan data lapangan meliputi 6 (enam) LMU. LMU 1, LMU 3, LMU 5 dan LMU 6 merupakan hutan tanaman eks-PT Perhutani yang diserahkan secara resmikepada Balai
Besar TNGGP pada tahun 2010. Kondisi LMU 2 adalah hutan alam, namun cenderung terbuka dan mayoritas merupakan lahan kosong, sementara LMU 4 berupa hutan alam 
primer dengan kondisi yang masih baik. Rekapitusai jumlah petak ukur dan intensitas sampling dalam pengambilan pettak ukur dapat dilihat pada Tabel 4.

Tabel 4. Rekapitulasi Jumlah PU, Intensitas Sampling dan Kondisi Umum

\begin{tabular}{crccl}
\hline LMU & Luas Ha & Jumlah PU & IS (\%) & \multicolumn{1}{c}{ Kondisi Lapangan } \\
\hline 1 & 117,99 & 10 & 0,339 & Lahan Eks-Perhutani berupa Hutan Tanaman \\
2 & 21,76 & 5 & 0,919 & Hutan Alam, Areal sedikit Terbuka \\
3 & 58,22 & 5 & 0,344 & Lahan Eks-Perhutani berupa Hutan Tanaman \\
4 & 40,90 & 30 & 2,934 & Hutan Alam \\
5 & 42,78 & 5 & 0,468 & Lahan Eks-Perhutani berupa Hutan Tanaman \\
6 & 7,07 & 5 & 2,829 & Lahan Eks-Perhutani berupa Hutan Tanaman \\
\hline
\end{tabular}

Pembuatan PU di LMU 1, LMU 2, LMU 3, LMU 5 dan LMU 6 tidak diteruskan hingga memenuhi intensitas sampling minimal 2\%, hal ini karena kondisi lapangan yang homogen tegakannya dan kondisi lantai hutan tidak terdapat komunitas tumbuhan bawah, kondisi lantai hutan LMU 1

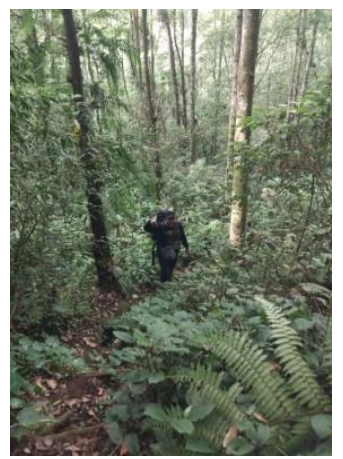

(a)

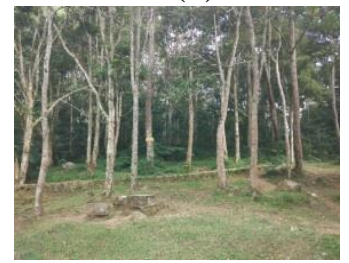

(c) dapat dilihat pada Gambar 10. (a), LMU 3. (b), LMU 5 pada. (c) dan LMU 6. (d). Pembuatan PU di LMU 1, LMU 2, LMU 3, LMU 5 dan LMU 6 tetap dilakukan untuk mengetahui kondisi biofisik lingkungan selain tetap dilakukan pengambilan data tumbuhan bawah.

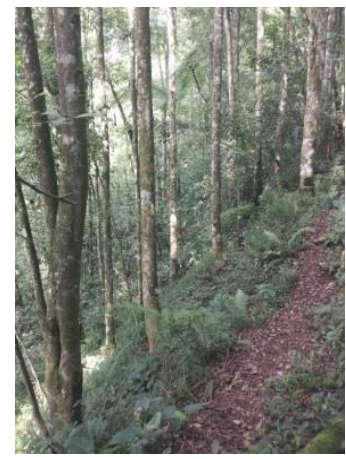

(b)

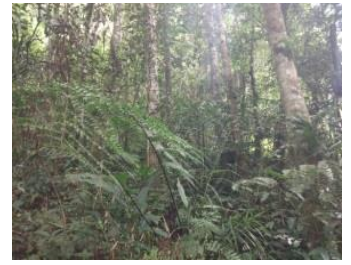

(d)

Gambar 10. Kondisi Lantai Hutan eks-PT Perhutani pada (a) LMU 1; (b) LMU 3; (c) LMU 5; (d) LMU 6

LMU 4 dan LMU 2 berupa hutan alam. LMU 2 cenderung diperuhi oleh belukar dan lahan kosong, sehingga ttupan tumbuhan bawah sedikit. LMU 4 merupakan lokasi yang sangat baik tutupan lantai hutan oleh tumbuhan bawah. LMU 4 merupakan LMU yang paling representatif, karena merupakan hutan alam yang masih terjaga kondisinya. Di LMU 4 dilakukan pembuatan 30 PU, dengan luas LMU 4 
sebesar 40,90 Ha maka diperoleh IS sebesar $2,93 \%$.

\section{Identifikasi Jenis Tumbuhan Bawah}

Identifikasi jenis tumbuhan bawah dilakukan di lokasi petak ukur dengan bantuan dari pengenal jenis lokal, untuk jenis yang memerlukan identifikasi lebih lanjut maka dilakukan pembuatan herbarium lalu diidentifikasi lebih mendalam di Laboratorium Botani LIPI Bogor. Pembuatan PU dan identifikasi jenis di LMU 1 ditemukan 28 jenis tumbuh an bawah, LMU 2 ditemukan 8 jenis, LMU 3 ditemukan 9 jenis, LMU 4 ditemukan 80 jenis, LMU 5 ditemu kan 13 jenis dan di LMU 6 ditemukan 5 jenis.

Setelah dilakukan identifikasi dan rekapitullasi data, ditemukan 83 jenis tumbuhan bawah yang berasal dari 45 famili. Dari jenis tumbuhan bawah yang telah teridentifikasi tersebut, dilakukan ekstraksi agar dapat dilakukan pengujian sitotok sisitas dan pengujian selektivitas. Famili tumbuhan bawah meliputi Acanthaceae, Annonaceae, Apiaceae, Apocynaceae, Araceae, Araliaceae, Aspleniaceae, Asteraceae, Balsamina ceae, Begoniaceae, Compositae, Convolvulaceae, Cucurbitaceae, Cype raceae, Elaeagnaceae, Equisetaceae, Fabaceae, Gesneriaceae, Gramineae, Hypoxidaceae, Lamiaceae, Malva ceae, Marattiaceae, Melastomataceae, Menispermaceae, Moraceae, Musa ceae, Myrsinaceae, Oxalidaceae, Passifloraceae, Piperaceae, Planta ginaceae, Polygalaceae, Primulaceae, Rosaceae, Rubiaceae, Sellagineaeeae, Smilaceae, Solanaceae, Symplo caceae, Urticaceae, Verbenaceae, Woodsiaceae, Zingiberaceae. Rekapi tulasi jenis tumbuhan bawah yang diperoleh di lokasi petak ukur di semua LMU pada penelitian ini dapat dilihat pada Tabel 5.

Tabel 5. Jenis Tumbuhan Bawah di Lokasi Petak ukur

\begin{tabular}{|c|c|c|}
\hline Spesies & Famili & Nama Lokal \\
\hline Strobilanthes blumei Bremek & Acanthaceae & Bubukuan gede \\
\hline Strobilanthes cernua B1. & Acanthaceae & Bubukuan kembang bidas \\
\hline Strobilanthes filiformis $\mathrm{Bl}$. & Acanthaceae & Bubukuan letik \\
\hline Orophea hexandra $\mathrm{Bl}$. & Annonaceae & Kisauheun \\
\hline Polyalthia subcordata Bl. & Annonaceae & Nona leuweung \\
\hline Centella asiatica (L.) Urb. & Apiaceae & Antanan / pegagan \\
\hline Sanicula elata Ham.ex D.Don. & Apiaceae & Seledri gunung \\
\hline Rauwolfia javanica $\mathrm{L}$ & Apocynaceae & Lame \\
\hline $\begin{array}{l}\text { Schismatoglottis calyptrata } \\
\text { (Roxb.) Zoll. }\end{array}$ & Araceae & Cariang \\
\hline Trevesia sundaica Miq. & Araliaceae & Panggang rante \\
\hline Asplenium nidus L. & Aspleniaceae & Kadaka \\
\hline Ageratum conyzoides $\mathrm{L}$. & Asteraceae & Babadotan \\
\hline Artemisia vulgaris $\mathrm{L}$. & Asteraceae & Rokat mala \\
\hline Bidens pilosa $\mathrm{L}$. & Asteraceae & Hareuga \\
\hline Blumea balsamifera (L) DC. & Asteraceae & Sembung gunung \\
\hline $\begin{array}{l}\text { Eupatorium inulifolium } \\
\text { (Kunth)R.M.King \& H.Rob }\end{array}$ & Asteraceae & Kirinjuh \\
\hline Eupatorium riparium Regel. & Asteraceae & Teklan \\
\hline Eupatorium sordidum L. & Asteraceae & Babakoan \\
\hline Impatiens platypetala Lindl. & Balsaminaceae & Pacar tere \\
\hline Begonia isoptera Dryand. & Begoniaceae & Hariang bodas \\
\hline Begonia robusta $\mathrm{Bl}$. & Begoniaceae & Hariang beureum \\
\hline
\end{tabular}


JURNAL TENGKAWANG (2017)

Vol. 7 (1) : 28 - 45

\begin{tabular}{|c|c|c|}
\hline Spesies & Famili & Nama Lokal \\
\hline Begonia sp. & Begoniaceae & Haring tangkal \\
\hline Gynura aurantiaca (Blume) DC. & Compositae & Santoloyo / sintrong \\
\hline $\begin{array}{l}\text { Tithonia diversifolia (Hemsl.) A. } \\
\text { Gray }\end{array}$ & Compositae & Rigow \\
\hline $\begin{array}{l}\text { Merremia umbellata }(\mathrm{L} .) \\
\text { Hallier.f. }\end{array}$ & Convolvulaceae & Areuy boboledan \\
\hline Bryonopsis laciniosa $\mathrm{L}$. & Cucurbitaceae & Koreh kotok \\
\hline Carex baccans Nees. & Cyperaceae & Rumput teki \\
\hline Elaeagnus latifolia $\mathrm{L}$. & Elaeagnaceae & Kicepot/kakaduan \\
\hline $\begin{array}{l}\text { Equisetum debile Roxb. ex } \\
\text { Vaucher. }\end{array}$ & Equisetaceae & Tataropongan/paku ekor kuda \\
\hline Euchresta horsfieldii Benn. & Fabaceae & Kojiwo \\
\hline $\begin{array}{l}\text { Pithecellobium clypearia (Jack) } \\
\text { Benth }\end{array}$ & Fabaceae & Haruman \\
\hline $\begin{array}{l}\text { Agalmyla parasitica } \\
\text { (Lam.)Kuntze }\end{array}$ & Gesneriaceae & Kitando \\
\hline Cyrtandra picta $\mathrm{Bl}$. & Gesneriaceae & Reundeu badak \\
\hline Cyrtandra populifolia Miq. & Gesneriaceae & Reundeu beureum \\
\hline $\begin{array}{l}\text { Imperata cylindrica (L.) } \\
\text { P.Beauv. }\end{array}$ & Gramineae & Eurih/alang-alang \\
\hline $\begin{array}{l}\text { Curculigo capitulata (Lour.) } \\
\text { Herb. }\end{array}$ & Hypoxidaceae & Congkok \\
\hline Coleus galeatus Benth.. & Lamiaceae & Jawerkotok leuweung \\
\hline Scutellaria discolor Colebr. & Lamiaceae & Hamperu tanah \\
\hline Hibiscus tiliaceus & Malvaceae & Bisoro \\
\hline Sida rhombifolia $\mathrm{L}$. & Malvaceae & Sanagori \\
\hline Sterculialongi folia Vent. & Malvaceae & Palahlar gede \\
\hline Urena lobata $\mathrm{L}$ & Malvaceae & Pungpurutan \\
\hline $\begin{array}{l}\text { Angiopteris evecta } \\
\text { (G.Forst.)Hoffm }\end{array}$ & Marattiaceae & Paku kebo \\
\hline $\begin{array}{l}\text { Medinilla speciosa } \text { Reinw.ex } \\
\text { Blume }\end{array}$ & Melastomataceae & Harendong bokor \\
\hline Medinilla verrucosa $\mathrm{B} 1$. & Melastomataceae & Harendong koneng \\
\hline Melastoma stigerum B1. & Melastomataceae & Harendong lalaki \\
\hline Clidema hirta (L).D.Don & Melastomataceae & Harendong bulu \\
\hline $\begin{array}{l}\text { Stephania venosa (Blume) } \\
\text { Spreng. }\end{array}$ & Menispermaceae & Geureung bodas \\
\hline Ficus deltoidea Jack. & Moraceae & Tobat barito \\
\hline Musa acuminata Colla. & Musaceae & Pisang kole \\
\hline Ardisia fuliginosa $\mathrm{B} 1$. & Myrsinaceae & Kiajag \\
\hline Embelia pergamacea A.DC. & Myrsinaceae & Kicemang gede \\
\hline Oxalis intermedia A. Rich. & Oxalidaceae & Calincing gede \\
\hline Passiflora edulis Sims. & Passifloraceae & Pasi \\
\hline Passiflora suberosa L. & Passifloraceae & Konyal \\
\hline Piper arcuatum C.Presl. & Piperaceae & Seureuh leuweung \\
\hline Piper baccatum $\mathrm{Bl}$. & Piperaceae & Seureuh kandel \\
\hline Piper sp. & Piperaceae & Seureuh tangkal \\
\hline Plantago major $\mathrm{L}$. & Plantaginaceae & Ki urat \\
\hline Polygala paniculata $\mathrm{L}$. & Polygalaceae & Akar wangi \\
\hline Polygala venenosa Juss.ex Poir. & Polygalaceae & Katutungkul \\
\hline Polygonum chinense L. & Polygonaceae & Bungbrun \\
\hline Embelia ribes Burm.f. & Primulaceae & Kicemang beurit \\
\hline Rubus sundaicus B1. & Rosaceae & Hareu'eus \\
\hline Anotis hirsuta (L.f.) Boerl & Rubiaceae & Kasimukan \\
\hline Lasianthus purpureus Bl. & Rubiaceae & Kahitutan tangkal \\
\hline Mussaenda frondosa $\mathrm{L}$. & Rubiaceae & Kingkilaban \\
\hline
\end{tabular}




\begin{tabular}{lll}
\hline Spesies & Famili & Nama Lokal \\
\hline Selaginella opaca Warb. & Sellagineaeeae & Paku rane \\
Smilax macrocarpa Bl. & Smilaceae & Canar \\
Brugmansia suaveolens Bercht & Solanaceae & Kucubung \\
\& J.Presl. & & \\
Cestrum elegans (Brongniart ex & Solanaceae & Kijogo beureum \\
Newmann) Schlechtendal. & Solanaceae & Cecenetan \\
Physalis peruviana L. & Solanaceae & Tekokak \\
Solanum torvum Sw. & Solanaceae & Teter \\
Solanum verbascifolium L. & Symplocaceae & Jirak \\
Symplocos javanica (Blume) & Kurtz. & \\
\hline
\end{tabular}

\section{PENUTUP}

Tumbuhan bawah yang terdapat di Taman Nasional Gunung Gede Pangrango terbagi atas 6 LMU. Jenis yang ditemukan sebanyak 83 jenis dan terdiri atas 45 famili.

\section{DAFTAR PUSTAKA}

Cutler, SJ. 2000. Biologically Active Natural Products: Pharmaceuticals. CRC Press, LLC, Boca Ratou, USA.

Hardjosumarno, S., 1998, Metode Ekologi, Fakultas Biologi UGM, Yogyakarta.

Hardjowigeno, S., 2003, Ilmu Tanah, Akademika Presindo, Jakarta.

Hilwan I, Mulyana D, Pananjung GW. 2013. Keanekaragaman Jenis Tumbuhan Bawah pada Tegakan Sengon Buto (Enterolobium cyclocarpum Griseb) dan Trembesi (Samanea saman Merr) di Lahan Pasca Tambang Batubara PT Kitadin, Embalut, Kutai Kartane gara, Kalimantan Timur. Jurnal Silvikultur Tropika Vol 04 No 1 April 2013 Hal 6-10. Departemen Silvikultur, Fakultas Kehutanan IPB. Bogor.

Marsono, D. 2004. Konservasi Sumber Daya Alam dan Lingkungan Hidup. Penerbit BIGRAF Publishing bekerjasama dengan

$\begin{array}{lrr}\text { Sekolah } & \text { Tinggi } & \text { Teknik } \\ \text { Lingkungan } & \text { (STTL) } & \text { Yogyakarta. } \\ \text { Yogyakarta } & & \end{array}$

Odum, E.P. 1993. Dasar-Dasar Ekologi. Edisi Ketiga. Yogyakarta. Universitas Gadjah Mada.

Searles, P.S., Flint, S.D., Caldwell, M.M., 2001, A Meta-Analysis of Plant Field Studies Simulating Stratospheric Ozone Depletion, Oecologia 127, 1-10.

Setyawan, A.D., Indrowuryatno, Wiryanto, Winarno, K., Susilowati, A., 2005, Tumbuhan Mangrove di Pesisir Jawa Tengah, Jurusan Biologi FMIPA, Universitas Sebelas Maret, Surakarta.

Smith, RL. 1990. Ecology and Field Biology Volume 4. Harper and Row. New York.

Soerianegara, I dan Indrawan A. 2008. Ekologi Hutan Indonesia. IPB. Bogor

Supriyono, 2009, Kandungan COrganik dan N-total pada Seresah dan Tanah pada 3 Tipe Fisiognomi (Studi Kasus di wanagama I, Gunung Kidul, DIY), Jurnal Ilmu tanah dan Lingkungan,Vol. 9 No. 1: 49-57. 
Whitmore, TC. 1984. Tropical Rain Forest of the Far East (Second Edition). Oxford University Press. New York.

Zainuddin. 2008. Pengantar Ekologi. CV Remadja Karya. Bandung

Zidorn, C., 2010, Altitudinal Variation of Secondary Metabolites in Flowering Heads of The
Asteraceae Trends and Causes, Journal of Phytochem 9: 1972003.

Zuhud, EAM. 2008. Potensi Hutan Tropika Indonesia sebagai Penyang ga Bahan Obat Alam untuk Keseha tan Bangsa. Fakultas Kehutanan Institut Pertanian Bogor. Bogor 